\title{
A week to remember
}

Dominique Goy-Blanquet

\section{(2) OpenEdition \\ Journals}

Electronic version

URL: http://journals.openedition.org/shakespeare/3156

DOI: 10.4000/shakespeare.3156

ISSN: 2271-6424

\section{Publisher}

Société Française Shakespeare

Electronic reference

Dominique Goy-Blanquet, " A week to remember », Actes des congrès de la Société française

Shakespeare [Online], 33 | 2015, Online since 10 March 2015, connection on 22 September 2020. URL : http://journals.openedition.org/shakespeare/3156 ; DOI : https://doi.org/10.4000/shakespeare.3156

This text was automatically generated on 22 September 2020.

(c) SFS 


\title{
A week to remember
}

\author{
Dominique Goy-Blanquet
}

1 After a long period of distrust, the French passion for Shakespeare suddenly erupted in September 1827 at the Théâtre de l'Odéon where the young generation of Romantic artists were gathered for a performance of Hamlet. "Shakespeare, falling upon me unawares, struck me like a thunderbolt, Berlioz remembers. His flash of lighting, opening up the heavens of art for me in a sublime blast, illuminated its farthest depths." In the audience with him were Victor Hugo, Delacroix, Vigny, Dumas, Nodier, Théophile Gautier, who made Shakespeare their standard bearer against the constraints of classicism and French elegancies. Shakespeare the moderate, a conservative by inclination or obligation, was promoted champion of all political and formal rebellions. It is this eruption, and the wave of masterpieces it inspired through the century that we aimed to revisit in celebrating Shakespeare's $450^{\text {th }}$ birthday, with the friendly help of the Odéon, the Delacroix et Victor Hugo museums, ComédieFrançaise, Bibliothèque nationale de France, the Louxor cinema, and the numerous partners who supported us in this adventure.

2 An adventure which continues. A collection of Lettres à Shakespeare addressed to him as one author to another by sixteen contemporary writers opens new forms of exchange. On Monday 21 April 2014, the opening of the Shakespeare 450 conference by Yves Bonnefoy with the question "Why Shakespeare?" inspired him with a long essay on Hamlet, soon to be published by Le Seuil, and a symposium at Fondation Hugot du Collège de France, whose acts will be published by Éditions Hermann. With him came the memory of Patrice Chéreau who was about to stage his translation of As You Like It in the Odéon's ateliers Berthier, when death put an end to their works, a loss deeply felt by all who remembered their Hamlet.

3 Then Andreas Höfele took us with Valéry in the wake of a revenant Hamlet through the churchyards of Europe after the Great War, and from there to Berlin in the Twenties, where Svend Gade and Asta Nielsen, Leopold Jessner and Fritz Kortner, went against the current tradition with two unorthodox productions, resisting the reactionary nostalgia and ambient cultural pessimism. This was a prelude to a screening of Svend Gade's Hamlet the following evening, with an original score by Robin Harris. The 
complete sequence of the Hamlet lithographs and stones exhibited at musée Delacroix revived the figure that had printed itself on the European imagination, while the BnF showed the fatal concatenation of diplomatic, political and military moves of the "Summer 14: the last days of the old world".

World War One was also Ton Hoenselaars' theme, marked by a renewed Entente cordiale between France and Great Britain, and the enrolment of Shakespeare against the common enemy who was attempting to appropriate him. This mobilisation has been fruitfully researched on both sides of the front line, but kept within the borderlines of each country, so Hoenselaars calls for an international team effort to exploit these neglected sources. Based "somewhere in France" as they write under the control of censorship, soldiers read and perform Shakespeare, leaving all memories of Agincourt behind, calling on Henry V to lead them to victory.

A visit to the collections of the Comédie-Française and its backstage, a diaporama of the "Arts du Spectacles" department at the BnF shown by Joël Huthwohl, a survey of the earliest French translations by Michèle Willems took us back to the early days of Shakespeare in France, evoked by Talma's armchair and the urn that replaced the unseemly ghost of King Hamlet. "The poor ghost was only tolerated backstage, Hugo ironised. A ghost is ridiculous, but 'ashes', O, ripping!" On 23 April, Shakespeare's official birthday, Peter Holland unrolled the history of its commemorations in England, where the poet became the object of an alternative cult, "the god of our idolatry", "the glory of our nation", from Garrick's Temple to the Stratford Jubilee, from the Poets' Corner in Westminster Abbey to the rest of the world. A history that paradoxically reflects the cultural anxieties and insecurities of the Englishness he was supposed to embody.

6 The philosopher Michèle le Dœuff added her testimony to the Shakespeare in France file with memories of a performance in Brittany where the school boys greeted Macbeth with a noisy rumpus. Two decades earlier, Simone de Beauvoir had bitterly diagnosed a deep dislike of Shakespeare among the critics. In Paris as in Quimper, the old antagonism survived against the barbarian who endangered the great masters of classical culture, Racine and Corneille. Le Dœuff's aesthetic conversion came from different sources, Claude Barma's televised adaptations, Aimé Césaire's revision of The Tempest, or the university companies who put on Shakespeare with little means and a considerable amount of thinking, and knew how to give pleasure to their audiences with high standards of approach. A pleasure which the conference participants could hope to experience that very evening with a choice of hearing Shakespeare sing or speak at the Opéra Bastille, Vieux-Colombier, or Cartoucherie de Vincennes where Ariane Mnouchkine had invited them to a runthrough of her forthcoming Macbeth.

7 Dominique de Font-Réaulx opened a new angle of approach by exploring the theatrical origins of photography through the works of Daguerre. A renowned scenographer for the theatre and the opera, Daguerre created lighting effects that were hailed as masterpieces in their own right, like the moonlight that shone on his set for $A$ Midsummer Night's Dream. The invention of the daguerréotype in 1838 owed as much to the theatre as it did to painting, with records of scenes previously composed to maintain the illusion of their representation. The theatre, then a favourite entertainment of the Parisians, was enjoying an exceptional renewal, magnified by the recent craze for Shakespeare, and made glamorous by the recent optical discoveries. Coinciding with Hugo's determination to open the stage to the whole world, Daguerre 
and Niépce invented the machine that would enable them to record it on photography. Parallel to the Hamlet sequence at musée Delacroix, the manuscripts and rich iconography exhibited by musée Victor Hugo recalled the major contribution of the poet and his son François-Victor to the re-actualisation of Shakespeare by the Romantics.

8 François Laroque drew on the works of the anthropologist school of Mauss and Dumézil to explore Shakespeare's outlook on the Elizabethan world, haunted by memories of a merry old England buried under the waste of political and religious divisions. He detected a patent ambivalence in Shakespeare's alternately critical and nostalgic interest in those vestiges. The Reformation had erased a number of traditional saints from the calendar, and strove to eliminate all traces of pagan or papist rituals, but traces of these remain, in the speech of popular characters, Falstaff's carnivalesque transgressions, riots, or talismans and fetishes like Desdemona's handkerchief. A special screening of Carné and Prévert's Children of Paradise at the Louxor cinema that evening took us with Othello on Boulevard du Crime, which according to Théophile Gautier was the only appropriate place where to perform Shakespeare: "There you have a real audience! not all those bored people in more or less yellow gloves; all those soiled, used up, jaded serialists, those marchionesses of the rue Helder, only concerned by their dresses and bouquets; an audience in blouse, shirt, or no shirt, arms naked, cap on the ear, but naïve as a child listening to the tale of Blue Beard, who surrender to the poet's fiction - yes, the poet - and accept everything, provided they are amused" (Shakespeare aux Funambules, 1842).

9 A different kind of palimpsest appears with the new technologies, TV serials and videogames, which no longer draw directly on the texts of the plays, Sarah Hatchuel shows, but appropriate former screen adaptations to create new fictions where both the literary and the filmic allusions are part of the intertextual game. Shakespeare remains a major presence on screen, but those are now divided screens, where he appears fragmented, in parodic modes, through shreds of quotations, images taken out of their original context, sound effects, characters armed with iPhones and other gadgets who google, tweet, email, mix, chat like the best of us, a Shakespeare both "present and absent".

Sunday 27 April, last stage of this journey into Shakespeare memory, a visit to the funeral effigies of the Saint-Denis basilica was concluded by Chantal Schütz and Yan Brailowsky's interpretations of Shakespearean songs and texts on the royal imagination. Some four hundred scholars from around the world had met in Paris to hear the lectures collected here, exchange thoughts and debate in sixty workshops, visit the exhibitions, theatre performances and concerts celebrating Shakespeare's 450th birthday. To all we wish a pleasant rereading of an eventful week together. 